\title{
IMPLEMENTASI STRATEGI PEMASARAN DENGAN MENGGUNAKAN METODE SWOT DALAM UPAYA MENINGKATKAN PENJUALAN PRODUK JASA ASURANSI KECELAKAAN DAN KEMATIAN PADA PT. PRUDENTIAL CABANG LAMONGAN
}

\author{
*(Puguh Cahyono \\ Prodi Manajemen, Fakultas Ekonomi, Universitas Islam Lamongan \\ $\mathrm{Jl}$. Veteran No.53A Lamongan \\ Telp. ( 0322 ) 324706, Faks. ( 0322 ) 324706 \\ Email:jpim.unisla@gmail.com
}

\begin{abstract}
ABSTRAK
Penelitian ini merupakan jenis penelitian kualitatif pada perusahaan asuransi dengan judul "Implementasi Strategi Pemasaran Dengan Menggunakan Metode Swot Dalam Upaya Meningkatkan Penjualan Produk Jasa Asuransi Kecelakaan Dan Kematian Pada PT. Prudential Cabang Lamongan”. Tujuan skripsi ini adalah untuk mendeskripsikan dari strategi pemasaran pada PT. Prudential. obyek penelitian menggunakan metode observasi, wawancara, dan dokumentasi. Sedangkan teknik analisa data menggunakan teknik analisa SWOT (Strengths, Weaknesses, Opportunities, Threats). Kesimpulan dari penelitian ini adalah untuk mengetahui implementasi strategi pemasaran dengan menggunakan metode SWOT dalam upaya meningkatkan penjualan produk jasa asuransi kecelakaan dan kematian.
\end{abstract}

Kata kunci : Analisis SWOT, Strategi pemasaran

\section{PENDAHULUAN}

Menurut pendapat Serdamayanti (2014;2) menyatakan bahwa strategi adalah rencana jangka panjang, diikuti tindakan yang di tujukan untuk mencapai tujuan tertentu, yang umumnya adalah tujuan "kemenangan". Asal kata "strategi" turunan dari kata dalam bahasa yunani, strategos.

Strategi adalah rencana yang di satukan, luas dan berintegrasi yang menghubungkan keunggulan strategi perusahaan dengan tantangan lingkungan, dirancang untuk memastikan tujuan utama dari perusahaan dapat di capai melalui pelaksanaan yang tepat oleh organisasi.

Freddy rangkuti (2013:101) menjelaskan bahwa pemasaran adalah suatu proses kegiatan yang di pengaruhi oleh berbagai faktor sosial, budaya, politik, ekonomi, dan manajerial.
Akibat dari pengaruh berbagai faktor tersebut adalah masing - masing individu maupun kelompok mendapatkan kebutuhan dan keinginan dengan menciptakan, menawarkan, dan menukarkan produk yang memiliki nilai komoditas.

Jasa dapat di definisikan sebagai setiap perbuatan ataupun kinerja yang dapat ditawarkan suatu pihak kepada pihak lain yang pada dasarnya bersifat tidak tampak (intangible) dan tidak mengakibatkan adanya perpindahan kepemilikan atas sesuatu. Proses produksinya bisa terikat atau tidak terikat pada sesuatu produk fisik. Gunawan Adisaputro (2010:183).

Berbagai riset dan literatur pemasaran jasa mengungkap bahwa jasa memiliki sejumlah karakteristik yang membedakannya dari barang dan berdampak pemasarannya. 
1. Aspek ketidak tampakan (intangibility)

Jasa memeng berbeda dengan barang. Bila barang merupakan suatu obyek, alat, atau benda; maka jasa adalah suatu perbuatan, tindakan, pengalaman, proses, kinerja (performance), atau usaha. Oleh sebab itu jasa tidak dapat dilihat, dirasa, dicium, didengar, atau diraba sebelum di beli dan di konsumsi.

2. Ketidak terpisahan (inseparability)

Barang biasanya di produksi, kemudian dijual, lalu di konsumsi. Sedangkan jasa umumnya di jual terlebih dahulu, baru kemudian diproduksi dan dikonsumsipada waktu dan tempat yang sama.

3. Kesulitan penyeragaman produk jasa (variability)

Jasa bersifat sangat variabel karena merupakan non-standardized output, artinya banyak variasi bentuk,kualitas dan jenis, tergantung pada siapa, kapan dan dimana jasa tersebut di produksi.

4. Kemungkinan (perishability)

disimpan

Perishability berarti bahwa jasa tidak tahan lama dan tidak dapat disimpan. Fandy tjiptono, Ph.D (2014:28-32).

Karena jasa mempunyai kualitas pengalaman dan kepercayaan yang tinggi, resiko dalam pembeliannya akan lebih banyak. Hal ini mengandung beberapa konsekuensi. Pertama, konsumen jasa umumnya mengandalkan cerita dari mulut kemulut dari pada iklan. Kedua, mereka sangat mengandalkan harga, petugas, dan petunjuk fisik untuk menilai mutunya. Ketiga, mereka sangat setia pada penyedia jasa yang memuaskan mereka. Perusahaan-perusahaan jasa menghadapi tiga tugas, yaitu meningkatkan diferensiasi persaingan, mutu jasa, dan produktivitas. Etta Mamang Sangadji, M.Si. dan Sopiah, MM M.Pd (2013:98).
Rumusan masalah pada penelitian ini adalah (1)Bagaimana implementasi strategi pemasaran dengan menggunakan metode SWOT dalam upaya meningkatkan penjualan produk jasa asuransi kecelakaan dan kematian pada PT. Prudential? (2)Strategi pemasaran apakah yang digunakan PT. Prudential Cabang Lamongan dalam upaya meningkatkan penjualan produk.

\section{LANDASAN TEORI}

Analisis SWOT adalah metode perencanaan strategis yang digunakan untuk mengevaluasi kekuatan atau Strengths, kelemahan atau Weaknesses, peluang atau Opportunities, dan ancaman atau Threast dalam suatu proyek atau suatu spekulasi bisnis. Dan dapat diterapkan dengan cara menganalisis dan memilah berbagai hal yang mempengaruhi keempat faktornya. Erwin Suryatama (2014:29)

Analisis Internal meliputi 1) Analisis Kekuatan (Strenght) Strenght atau kekuatan adalah situasi atau kondisi yang merupakan kekuatan dari perusahaan. Strenght merupakan faktor internal yang mendukung perusahaan dalam mencapai tujuannya. Faktor pendukung dapat berupa teknologi, sumber daya, keahlian, kekuatan pemasaran, dan basis pelanggan yang dimiliki atau kelebihan lain yang mungkin diperoleh berkat sumber keuangan, citra, keunggulan dipasar, serta hubungan baik antara buyer dengan supplier. 2) Analisis Kelemahan (Weaknesses) Weaknesses atau kelemahan adalah kegiatan-kegiatan yang tidak berjalan dengan baik atau sumber daya yang dibutuhkan oleh perusahaan tetapi tidak dimiliki oleh perusahaan. Kelemahan itu terkadang lebih mudah dilihat dari pada sebuah kekuatan, namun ada beberapa hal yang menjadikan kelemahan itu tidak diberikan solusi yang tepat dikarenakan tidak dimaksimalkan kekuatan yang sudah ada. Weaknesses merupakan 
faktor internal yang menghambat perusahaan dalam mencapai tujuannya. Faktor penghambat dapat berupa fasilitas yang tidak lengkap, kurangnya sumber keuangan, kemampuan mengelola, keahlian pemasaran, dan citra perusahaan.

Analisis Eksternal 1) Analisis

Peluang (Oppurtunity) Oppurtunity atau peluang adalah faktor positif yang muncul dari lingkungan dan memberikan kesempatan bagi perusahaan untuk memanfaatkannya. Oppurtunity merupakan faktor eksternal yang mendukung perusahaan dalam mencapai tujuannya. Faktor eksternal yang mendukung dalam pencapaian tujuan dapat berupa perubahan kebijakan, perubahan teknologi, perkembangan ekonomi dan perkembangan hubungan supplier dan buyer. 2) Analisis Ancaman (Threat) Threat atau ancaman adalah faktor negatif dari lingkungan yang memberikan hambatan bagi berkembangnya atau berjalannya sebuah perusahaan. Ancaman ini adalah hal yang terkadang selalu terlewatkan dikarenakan banyak yang ingin mencoba untuk kontroversi atau melawan arus. Namun, pada kenyataanya perusahaan tersebut lebih banyak layu sebelum berkembang. Threat merupakan faktor eksternal yang menghambat perusahaan dalam mencapai tujuannya. Faktor eksternal yang menghambat perusahaan dapat berupa masuknya pesaing baru, pertumbuhan pasar yang lambat, meningkatnya bergaining power dari pada supplier dan buyer utama, perubahan teknologi serta kebijakan baru. Erwin Suryatama (2014:27).

Pada umumnya asuransi jiwa adalah suatu asuransi yang bertujuan menanggung orang terhadap kerugian finansial yang tak terduga, yang disebabkan karena meninggalnya terlalu cepat atau pun hidupnya terlalu lama. Atau definisi asuransi jiwa yaitu suatu kontrak perjanjian antara pemegang polis dengan perusahaan asuransi atau insurer, yang dimana pihak asuransi berjanji untuk membayarkan nominal uang kalau terjadi resiko kematian terhadap pihak pemegang asuransi/polis.

Adapun tujuan dari penelitian ini adalah (1) Untuk mengetahui implementasi strategi pemasaran dengan menggunakan metode SWOT dalam upaya meningkatkan penjualan produk jasa asuransi kecelakaan dan kematian pada PT. Prudential. 2) Untuk mengetahui strategi pemasaran apakah yang digunakan PT. Prudential Cabang Lamongan dalam upaya meningkatkan penjualan produk

\section{METODELOGI PENELITIAN}

Jenis penelitian yang digunakan oleh penulis adalah deskriptif kualitatif. Penelitian dengan menggunakan deskriptif adalah penelitian yang berkenaan dengan pertanyaan terhadap keberadaan variabel mandiri, baik pada satu variabel atau lebih. Sugiyono (2013:35)

Menurut Sugiyono (2010:62) Sampel adalah bagian dari jumlah dan karakteristik yang dimiliki oleh populasi. Bila populasi besar dan peneliti tidak mungkin mempelajari semua yang ada pada populasi , misalnya karena keterbatasan dana, tenaga dan waktu maka peneliti dapat menggunakan sampel yang diambil dari populasi itu. Apa yang dipelajari dari sampel, kesimpulannya akan dapat diberlakukan untuk populasi. Untuk itu sampel yang diambil harus benar-benar representative (mewakili). Yang dijadikan sempel dalam penelitian ini adalah pekerja sebanyak 30 orang, nasabah sebanyak 50 orang, dan nasabah pesaing 20 orang. Dalam penelitian ini digunakan beberapa istilah sehingga didefinisikan secara operasional agar menjadi petunjuk dalam penelitian ini sebagai berikut: 1) 
Strategi pemasaran merupakan suatu cara atau alat yang dilakukan perusahaan untuk mencapai suatu tujuan dalam kaitannya dengan tujuan jangka panjang melalui kegiatan pemasaran. Danang sunyoto(2013:1) 1 . SWOT (Srenghts, Weaknesses ,Opportunities dan Threats) adalah pendekatan analisis untuk menentukan formulasi strategi pemasaran perusahaan di masa mendatang. Strenghts (kekuatan) adalah faktorfaktor internal perusahaan yang mendukung atau mempunyai keunggulan untuk pencapaian perkembangan pasaran. Weaknesses (Kelemahan) adalah faktor-faktor internal perusahaan yang menghambat atau membatasi perkembangan pasar. Opportunities (peluang) adalah faktorfaktor di luar lingkungan perusahaan yang menguntungkan dalam perkembangan pasar. a. Threats (Ancaman) adalah faktor-faktor di luar lingkungan perusahaan yang merupakan ancaman bagi perusahaan sehingga menghambat perkembangan pasar. Erwin Suryatama (2014:27). b. IFAS adalah Internal Factors Analysis Summary, yaitu kesimpulan analisis dari berbagai faktor internal yang mempengaruhi keberlangsungan perusahaan. c. EFAS adalah External Factors Analysis Summary, yaitu kesimpulan analisis dari berbagai faktor eksternal yang mempengaruhi keberlangsungan perusahaan. Freddy rangkuti (2014:26).

Analisis data adalah proses penederhanaan data ke dalam bentuk mudah dibaca dan diinterprestasikan. Data ini mencakup tentang pelaksanaan pelayanan, persaingan, strategi,dan lainlain. Dalam melakukan analisa data dilakukan dalam beberapa tahap Sugiono (2013:60)

Analisa Lingkungan Eksternalinternal Analisa ini dimaksudkan untuk mengetahui faktor-faktor internal dan eksternal perusahaan. Faktor-faktor internal dan eksternal kemudian diberi skor setelah sebelumnya dilakukan pembobotan dan penetapan rating. Kemudian diperoleh total skor yang akan menggambarkan kondisi usaha perusahaan dengan strategi yang telah disiapkan. Analisis swot adalah identifikasi berbagai faktor untuk merumuskan strategi perusahaan. Analisis ini didasarkan pada logika yang dapat merumuskan kekuatan (Strengths) dan peluang (Opportunities),namun secara bersamaan dapat meminimalkan kelemahan (Weaknesses) dan ancaman (Threats). Perencanaan strategis harus menganalisis faktor-faktor strategis perusahaan

(kekuatan,kelemahan,peluang dan ancaman) dalam kondisi yang ada saat ini. Hal ini disebut dengan analisis situasi. Model yang paling popular untuk analisis situasi adalah Analisis SWOT. Rangkuti (2014:19).

Alat yang dipakai untuk menyusun faktor-faktor strategis perusahaan adalah matriks SWOT atau disebut juga dengan matriks TOWS. Matriks ini dapat menggambarkan secara jelas bagaimana peluang dan ancaman eksternal yang dihadapi perusahaan dapat disesuaikan dengan kekuatan dan kelemahan yang dimilikinya.

Matriks ini dapat menghasilkan empat set kemungkinan alternative strategis.

a. Strategi SO

Strategi ini dibuat berdasarkan jalan pikiran perusahaan,yaitu dengan memanfaatkan seluruh kekuatan untuk merebut dan memanfaatkan peluang sebesarbesarnya.

b. Strategi ST

Ini adalah strategi dalam menggunakan kekuatan yang dimiliki perusahaan untuk mengatasi ancaman.

c. Strategi WO 
Strategi ini diterapkan berdasarkan permanfaatan peluang yang ada dengan cara meminimalkan kelemahan yang ada.

d. Strategi WT

Strategi ini didasarkan pada kegiatan yang bersifat defensive dan berusaha meminimalkan kelemahan yang ada,serta menghindari ancaman. Freddy rangkuti (2014:84).

\section{Matriks Faktor Strategi Eksternal}

Sebelum menggunakan matriks faktor strategi eksternal, kita perlu mengetahui terlebih dahulu faktor strategi eksternal (EFAS). Berikut ini adalah cara-cara menentukan faktor strategi eksternal:

a. Susunlah dalam kolom 1 (5 sampai dengan 10 peluang dan ancaman).

b. Beri bobot masing-masing faktor dalam kolom 2, mulai dari 1,0 (sangat penting) sampai dengan 0,0 (tidak penting). Faktor-faktor tersebut kemungkinan dapat memberikan dampak terhadap faktor strategis.

c. Hitung rating (dalam kolom 3) untuk masing-masing faktor dengan memberikan skalamulai dari 4 (outstanding) sampai dengan 1 (poor) berdasarkan pengaruh faktor tersebut terhadap kondisi perusahaan yang bersangkutan. Pemberian nilai rating untuk faktor peluang bersifat positif (peluang yang semakin besar diberi rating +4 , tetapi jika peluangnya kecil,diberi rating +1 ). Pemberian nilai rating ancaman adalah kebalikannya. Misalnya, jika nilai ancamannya sangat besar, ratingnya adalah 1 . Sebaliknya, jika nilai ancamannya sedikit maka ancamannya 4 . d. Kalikan bobot pada kolom 2 dengan rating pada kolom 3, untuk memperoleh faktor pembobotan dalam kolom 4 . Hasilnya berupa skor pembobotan untuk masingmasing faktor yang nilainya bervariasi mulai dari 4,0 (outstanding) sampai dengan 1,0 (poor).

e. Gunakan kolom 5 untuk memberikan komentar atau catatan mengapa faktor-faktor tertentu dipilih dan bagaimana skor pembobotannya dihitung.

f. Jumlahkan skor pembobotan (pada kolom 4), untuk memperoleh total skor pembobotan bagi perusahaan yang bersangkutan. Nilai total ini menunjukkan bagaimana perusahaan tertentu bereaksi terhadap faktor-faktor strategis eksternalnya. Total skor ini dapat digunakan untuk membandingkan perusahaan ini dengan perusahaan lainnya dalam kelompok industri yang sama.

\section{Matriks Faktor Strategi Internal}

Setelah faktor-faktor strategis internal suatu perusahaan diidentifikasi, suatu tabel IFAS (Internal Strategic Factor Analysis Summary) disusun untuk merumuskan faktor-faktor strategis internal tersebut dalam kerangka Strength and Weakness perusahaan. Tahapnya adalah: a.Tentukan faktor yang menjadi kekuatan serta kelemahan perusahaan dalam 1 kolom. b. Beri bobot masing-masing faktor tersebut dengan skala mulai dari 1,0 (paling penting) sampai 0,0 (tidak penting), berdasarkan pengaruh faktor-faktor tersebut terhadap posisi strategis perusahaan. (semua bobot tersebut jumlahnya tidak boleh melebihi skor total 1,00 ). 
a. Hitung rating (dalam kolom 3) untuk masing-masing faktor dengan memberikan skala mulai dari 4 (outstanding) sampai dengan 1 (poor), berdasarkan pengaruh faktor tersebut terhadap kondisi perusahaan yang bersangkutan. Variabel yang bersifat positif (semua variabel yang masuk kategori kekuatan) diberi nilai mulai dari +1 sampai dengan +4 (sangat baik) dengan membandingkannya dengan ratarata industri atau dengan pesaing utama. Sedangkan variabel yang bersifat negatif, kebalikannya. Contohnya, jika kelemahan perusahaan besar sekali dibandingkan dengan rata-rata industri, nilainya adalah 1, sedangkan jika kelemahan perusahaan dibawah rata-rata industri, nilainya adalah 4 .

b. Kalikan bobot pada kolom 2dengan rating pada kolom 3, untuk memperoleh faktor pembobotan dalam kolom 4 . Hasilnya berupa skor pembobotan untuk masing-masing faktor yang nilainya bervariasi mulai dari 4,0 (outstanding) sampai dengan 1,0 (poor).

c. Gunakan kolom 5 untuk memberikan komentar atau catatan mengapa faktor-faktor tersebut dipilih, dan bagaimana skor pembobotannya dihitung.

d. Jumlahkan skor pembobotan (pada kolom 4), untuk memperoleh total skor pembobotan bagi perusahaan yang bersangkutan. Nilai total ini menunjukkan bagaimana perusahaan tertentu bereaksi terhadap faktor-faktor strategis internalnya. Skor total ini dapat digunakan untuk membandingkan perusahaan ini dengan perusahaan lainnya dalam kelompok industri yang sama.
Pada dasarnya alternative strategi yang diambil harus diarahkan pada usaha-usaha untuk menggunakan kekuatan dan memperbaiki kelemahan, memanfaatkan peluang-peluang bisnis serta mengantisipasi ancaman. Sehingga dari matriks SWOT tersebut akan diperoleh empat kelompok alternative strategi yang disebut dengan strategi SO, strategi WO, strategi ST, dan strategi WT.

Diagram Analisis Swot

Kuadran 1 : Ini merupakan situasi yang sangat menguntungkan.

Perusahaan tersebut memiliki peluang dan kekuatan sehingga dapat memanfaatkan peluang yang ada. Strategi yang harus diterapkan dalam kondisi ini adalah mendukung kebijakan pertumbuhan yang agresif.

Kuadran 2 : Meskipun menghadapi berbagai ancaman, perusahaan ini masih memiliki kekuatan dari segi internal. Strategi yang harus diterapkan adalah menggunakan kekuatan untuk memanfaatkan peluang jangka panjang dengan cara strategi diversifikasi (produk/pasar).

Kuadran 3 : Perusahaan menghadapi peluang pasar yang sangat besar, tetapi dilain pihak, ia menghadapi beberapa kendala/kelemahan internal. Fokus strategi perusahaan ini adalah meminimalkan masalahmasalah internal perusahaan sehingga dapat merebut peluang pasar yang lebih baik. 
Kuadran 4 : Ini merupakan situasi yang tidak menguntungkan, perusahaan tersebut menghadapi berbagai ancaman dan kelemahan internal.

\section{HASIL PENELITIAN DAN PEMBAHASAN}

Strength

- Dukungan Pelayanan Tekn ologi Informasi (SFA), sehingga pekerjaan cepat, akurat dan transparan

- Dukungan SDM yang memadai baik untuk staf kantor maupun kuantitas agen

- Mempunyai citra yang baik dimata masyarakat

- Memberikan pelatihan kepada agen pemasaran untuk meningkatkan kualitas agen pemasaran

- Menjadi pemimpin pasar untuk Weakness kategori produk inovatif

- Fasilitas yang kurang memadai

- Jaringan kantor perlu diperluas

- Pelayanan proses administrasi diperlukan peningkatan

- Perlu pemerataan kualitas SDM terutama dikeagenan

- Persepsi negatif masyarakat terhadap asuransi di Indonesia

\section{Opportunities}

- Masyarakat semakin meminati produk asuransi

- Pola hidup masyarakat yang berubah (menuju pertumbuhan ekonomi yang lebih baik)

- Perkembangan teknologi semakin pesat

- Adanya kepercayaan nasabah

- Adanya peningkatan jumlah nasabah

\section{Threats}

- Perusahaan pesaing baru yang terus bermunculan
- Pesaing mulai untuk meluaskan wilayah penjualannya

- Kompetitor mulai meniru inovasi produk yang dikembangkan

- Ketidak stabilan teknologi

- Munculnya produk - produk baru yang sejenis yang ditawarkan

\section{Matrik Faktor Strategi Internal} (IFAS)

Setelah faktor-faktor strategi internal suatu perusahaan diidentifikasi, suatu tabel IFAS disusun untuk merumuskan faktorfaktor strategi internal tersebut dalam kerangka Strenght and Weakness. kemudian dengan dihitung untuk menentukan nilai bobot, rating dan skornya. Pada matrik pembobotan atas faktor strategi internal (IFAS) diperoleh skor total 3,32 yang dapat dikategorikan "baik" atau kondisi internal PT. Prudential Cabang Lamongan adalah cukup kuat. Berarti dapat dikatakan bahwa strategi internal kekuatan dan kelemahan yang dimiliki PT. Prudential Cabang Lamongan dimungkinkan sebagai landasan perusahaan untuk melaksanakan rencana-rencana pertumbuhan dan perkembangan dalam rangka mengantisipasi tantangan kedepan. Sehingga dapat memanfaatkan kekuatan yakni :

a) Dukungan pelayanan teknologi informasi (SFA), sehingga pekerjaan cepat, akurat dan transparan.

b) Dukungan SDM yang memadai baik untuk staf kantor maupun kuantitas agen

c) Mempunyai citra yang baik dimata masyarakat

d) Memberikan pelatihan kepada agen pemasaran untuk 
meningkatkan kualitas agen pemasaran

e) Menjadi pemimpin pasar untuk kategori produk inovatif

Dan memperkecil kelemahan yakni :

a) Fasilitas yang kurang memadai

b) Jaringan kantor perlu diperluas

c) Pelayanan proses administrasi diperlukan peningkatan

d) Perlu pemerataan kualitas SDM terutama dikeagenan

e) Persepsi negatif masyarakat terhadap asuransi di Indonesia

\section{Matrik faktor strategi eksternal} (EFAS)

Sedangkan pada matrik pembobotan eksternal (EFAS) hasil nilai skor totalnya adalah sebesar 2,92 dan dapat dikategorikan sebagai kondisi nilai yang baik. Dengan kondisi yang baik menunjukkan bahwa faktor-faktor eksternal perusahaan amat terbuka lebar,dimana bahwa dapat memanfaatkan peluang-peluang yakni :

a) Masyarakat semakin meminati produk asuransi

b) Pola hidup masyarakat yang berubah (menuju pertumbuhan ekonomi yang lebih baik)

c) Perkembangan teknologi semakin pesat

d) Adanya kepercayaan nasabah

e) Adanya peningkatan jumlah nasabah

Dan menghindari ancaman yakni :

a) Perusahaan pesaing baru yang terus bermunculan

b) Pesaing mulai untuk meluaskan wilayah penjualannya

c) Kompetitor mulai meniru inovasi produk yang dikembangkan

d) Ketidak stabilan teknologi

e) Munculnya produk - produk baru yang sejenis yang ditawarkan

\section{Perumusan Alternatif Strategi}

Selanjutnya untuk menyusun formulasi alternative-alternatif strategi PT. Prudential mempergunakan matrik SWOT,alternatif-alternatif strategi disusun berdasarkan interaksi atas faktor internal dam eksternal perusahanan untuk memperoleh strategi kompetitif.

\section{Strategi SO}

1. Peluang untuk selalu melakukan inovasi terhadap produk yang diluncurkan

2. Dengan jumlah SDM dan jaringan yang luas mempermudah penetrasi ke pasar

3. Pemanfaatan Teknologi Informasi untuk mempertahankan basis customer yang sudah ada dan membuka basis customer baru

4. Citra perusahaan yang baik menjadi sebuah nilai jual terhadap customer

\section{Strategi ST}

1. Terus melakukan inovasi terhadap produk yang diluncurkan

2. Memberikan edukasi kepada masyarakat mengenai manfaat asuransi dengan memanfaatkan jaringan keagenan yang dimiliki

\section{Strategi WO}

1. Secara terus menerus memperbaiki program pelatihan untuk SDM dengan mengevaluasi tingkat keberhasilan program pelatihan SDM yang sudah dijalankan

2. Memperluas jaringan keagenan dengan membuka program partnership dengan penyedia jasa lainnya (misalnya : bank, perusahaan telekomunikasi, perusahaan otomotif dsb) 
3. Secara terus menerus melakukan evaluasi terhadap proses administrasi untuk meningkatkan layanan terhadap customer

\section{Strategi WT}

1. Terus berinovasi agar dapat meluncurkan produk yang unik sehingga menarik minat calon customer

2. Bekerjasama dengan dunia pendidikan untuk memberikan edukasi tentang manfaat asuransi kepada masyarakat

Akibatnya posisi Prudential terletak pada kuadran I,karena kedua selisih nilai tertimbang adalah positif,yakni $\quad 0,62$ dan 0,39 . Manajemen Prudential diseyogyakan untuk mengimplementasikan strategi pertumbuhan.

Kuadran I : Ini merupakan situasi yang menguntungkan, PT Prudential Cabang Lamongan tersebut memiliki peluang dan kekuatan sehingga dapat memanfaatkan peluang yang ada. Strategi yang harus ditetapkan dalam kondisi ini adalah mendukung kebijkan pertumbuhan yang agresif (Growth Oriented Strategy)

\section{KESIMPULAN DAN SARAN Kesimpulan}

Berdasarkan hasil analisa yang telah dilakukan peneliti terhadap perusahaan kesimpulan yang dapat diambil peneliti adalah :

1. Berdasarkan diagram bobot dan rating setiap unsur matrik SWOT dapat diketahui bahwa posisi perusahaan atau instansi PT. Prudential Cabang Lamongan pada saat ini berada pada kuadran I merupakan situasi yang sangat menguntungkan. Perusahaan PT. Prudential cabang lamongan memiliki Koordinat Internal : (skor total kekuatan - skor total kelemahan) $=1,97-1,35=0,62$. Koordinat Eksternal : 1,79-1,40 = 0,39 . Jadi titik koordinatnya terletak pada $(0,62 ; 0,39)$ sehingga dapat memanfaatkan peluang yang ada. Strategi yang harus diterapkan dalam kondisi ini adalah mendukung kebijakan pertumbuhan yang agresif dimana strategi umum yang dapat dilakukan oleh perusahaan adalah menggunakan kekuatan dan peluang perusahaan untuk mengambil setiap keunggulan pada kesempatan yang ada.

2. Strategi yang bisa diterapkan adalah strategi agresif yaitu dengan meningkatkan akses pasar yang lebih luas, akses area layanan, meningkatkan kualitas jasa, mengembangkan produk baru, melakukan kemitraan, dan melakukan pengembangan internal dan eksternal.

\section{Saran}

Prudential akan lebih bisa memperkuat posisi perusahaan dalam meningkatkan perkembangan perusahaan dengan cara memperkuat pemasaran, lebih jeli melihat kelemahan pendatang baru, melakukan investasi dalam menjaga produktifitas yang efektif dan efisien melalui teknologi maupun tenaga kerja, dan fokus berusaha mengelola perusahaan melalui evaluasi yang berkelanjutan.

\section{DAFTAR PUSTAKA}

Adisaputro, Gunawan, 2010. Manajemen Pemasaran. Yogyakarta : Sekolah Tinggi Ilmu Manajemen YKPN.

P.Siagian, Sondang, 2011. Manajemen Startejik. Cetakan ke 9, Jakarta : PT Bumi Aksara 
Pedoman Penulisan Skripsi, 2014

Fakultas Ekonomi, Lamongan:

Universitas Lamongan

Rangkuti, Freddy, 2014, Analisis SWOT. Cetakan kedelapan belas. Jakarta : Gramedia Pustaka Utama

Sangadji, Etta Mamang dan sopiah, 2013. Perilaku Konsumen. Edisi 1, Yogyakarta : ANDI

Sedarmayanti, 2014, Manajemen Strategi. Cetakan kesatu. Bandung : PT. Refika Aditama

Sugiyono, 2010, Metode Penenlitian Kuantitatif dan Kualitatif, Bandung, Alfabeta

Sunyoto, Danang, 2013. Perilaku Konsumen. Cetakan pertama. Yogyakarta : CAPS

Suryatama, Erwin, 2014. Analisis SWOT. Cetakan pertama. Surabaya : Kata Pena

Tjiptono, Fandy, 2014. Pemasaran Jasa. Yogyakarta : Percetakan ANDI. 